\title{
Model of e-Learning Acceptance and Use for Teaching Staff in Higher Education Institutions
}

\author{
Mirjana Kocaleva \\ E-learning Center - University “Goce Delcev", Stip, 2000, R.Macedonia \\ Email: mirjana.kocaleva@ugd.edu.mk \\ Igor Stojanovic, Zoran Zdravev \\ Faculty of Computer Science - University "Goce Delcev", Stip, 2000, R.Macedonia \\ Email: \{igor.stojanovik, zoran.zdravev\}@ugd.edu.mk
}

\begin{abstract}
We live in a world where we are exposed to everyday changes that information and communication technologies (ICT) give us impose. These changes are largely related to education, and so the introduction of ICT in universities as institutions of higher education, clearly changing the way it is implemented. The policy of "Goce Delcev" University (UGD) is to fully implement ICT in all segments of management, administration and teaching. For this purpose, several projects for e-learning implementation at UGD have been conducted. But, as much as important introduction is, the more important is the acceptance of new technologies in education. Therefore, we shall use a modified Unified Theory of Acceptance and Use of Technology (UTAUT) as the research methodology. The purpose of this paper is understanding teaching staff acceptance and use eLearning system (ELC) and investigating the influence of seven determinants (four UTAUT determinants, 2 additional determinants and one personal "selfconfidence" determinant). A survey was administered to 92 respondents (teaching staff) to capture their perceptions of e-learning. The findings of this research show that among the seven UTAUT factors, the effort expectancy and facilitating conditions have the strongest effect of intention to use new technology. Also according to the survey, social influence and facilitating conditions are in strongest correlation with the behavioral intention and thereby the most influence on the behavior of participants for acceptance and use of the e - learning system.
\end{abstract}

Index Terms-ICT, UTAUT, education, e-learning, Moodle.

\section{INTRODUCTION}

In the first decade of the 21 st century e-learning has become one of the key factors of the revolution in the learning process. E - Learning combines modern interactive learning methods with knowledge management methods and offers a better evaluation of knowledge. Today, January 2015, undisputed is the fact that ICTs have a significant impact in the process of education. The presence of ICT in education contributes to significant changes in the teaching process. Electronic learning or e - learning, as one of the benefits of using ICT, includes acquisition, generation and transfer of knowledge. However, the technologies for improved productivity must be accepted and used by employees in organizations. The explanation of customer acceptance of new technology is often described as one of the most researched areas in modern literature information systems (Hu et al. 1999). Studies in this area have resulted in several theoretical models which have their roots in information systems, psychology and sociology (Davis et al. 1989; Taylor and Todd 1995b; Venkatesh and Davis 2000).

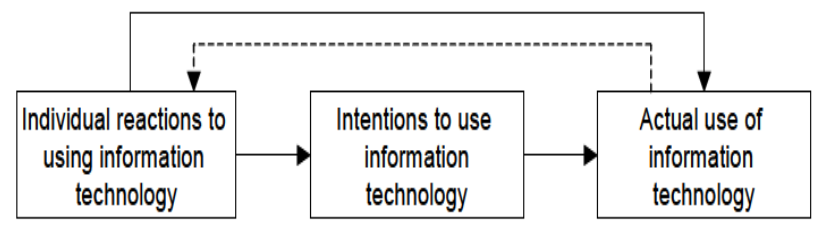

Fig. 1. Basic Concept Underlying User Acceptance Models (Venkatesh et al. 2003)

Figure 1 presents the basic conceptual framework underlying class of models, explaining the individual acceptance of information technology that is the basis of this research (Venkatesh et al. 2003).

Often are doing researches why people accept or reject new ICTs. There are a lot of conditions that must be met before these technologies can be introduced, adopted and spread to higher education institutions. Initiated in 2003 by Venkatesh is UTAUT theory, as well as its modified versions from 2008 and 2012 respectively. In the version of UTAUT of 2008 there are some changes in the schedule of the factors affecting the acceptance of new technologies and new three key factors, while the model of 2012 was extended and was intended for the consumer sector. Up to today this theory is very topical in many areas of our environment, but we pay special attention of what is its application in higher education institutions.

In this paper we describe the UTAUT theory, the factors that affect it and its application conducted by a survey in which the academic staff (professors, assistant professors and lecturers) from all 13 faculties of the University "Goce Delcev" - Stip will be included. The 
main aim of this research is to gain a complete picture of the acceptance and use of the system for e - learning by the teaching staff at the university. According to our research this topic is very actual and interesting in the world and for that reason surveys and researches on the acceptance of certain new technology are constantly conducted, but it is not the case in Macedonia. That is why it is even more challenging for us to thoroughly explore this topic. We expect to get results that will show whether and to what extent UTAUT will be acceptable for this type of information systems, in environment and conditions similar to higher education in our country i.e. in conditions where IT culture is lower. As a second result we expect to identify influential factors for the theory that most stands out in our environment.

\section{UTAUT}

Information technology accepts researches that gave many competing models for acceptance and use of information and communication technologies, each model with different acceptance of determinants. Each theory or model has been widely tested to predict user acceptance (Venkatesh and Davis, 2000; Thompson et al., 1991). However, no comprehensive instrument to measure the variety of perceptions of information technology innovations had existed until Venkatesh et al. (2003) attempted to review and compare the existing user acceptance models with an ultimate goal to develop a unified theory of technology acceptance by integrating every major parallel aspect of user acceptance determinants from those models.

The eight original models and theories of individual acceptance that are synthesized by Venkatesh et al. (2003) are: the Theory of Reasoned Action (TRA), Technology Acceptance Model (TAM), Motivational Model (MM), Theory of Planned Behavior (TPB), Combined TAM and TPB (C-TAM-TPB), Model of PC Utilization (MPCU), Innovation Diffusion Theory (IDT) and Social Cognitive Theory (SCT). Researchers are faced with a choice among variety of models and know that they have to "choose" factors across models, or to choose "favorite model" and to ignore the contributions of alternative models. Thus, there is a need to review and synthesize in order to progress towards a unified view of user acceptance.

Based on the conceptual and empirical similarities across models, a single model is formulated and now a unified theory of acceptance and use of technology (UTAUT) is often used. UTAUT was tested using the original data and overcoming of the eight individual models was found. UTAUT has become a useful tool that managers need to apply in order to evaluate the probability of success while introducing a new technology and helps in understanding the factors for its acceptance, in order to undertake more active interventions (such as training or marketing) targeted at users who may be less prone to adopt and use new systems (Venkatesh et al. 2003). UTAUT aims to explain user intention to use information systems and subsequently to monitor the behavior of their use. The theory considers that four key factors (performance expectancy, effort expectancy, social influence and facilitating conditions) are direct determinants of intention and usage behavior. Gender, age, experience and voluntary use are set to mediate between the impacts of the four key factors of the intention to use and the behavior (Venkatesh et al., 2003, Figure 2).

The UTAUT theory considers that three key factors (performance expectancy, effort expectancy and social influence) are direct determinants of behavioral intention to use technology, whereas the facilitating conditions are direct determinant for use behavior. The model integrates four intermediate factors like gender, age, experience and voluntary use, which have different impacts on basic constructions. Resuming, we can say that the UTAUT model condenses 32 variables from eight existing models into four main effects and four intermediate factors. Performance expectancy (PE) is the degree to which an individual believes that using a particular system would improve his or her job performance. Effort expectancy (EE) is the degree of simplicity associated with the use of a particular system. Social influence (SI) is the degree to which an individual perceives that others believe he or she should use a particular system. Facilitating conditions (FC) is the degree to which an individual believes that an organizational and technical infrastructure exists to support the use of a particular system. Gender roles have a strong psychological basis and are enduring. Age has an effect on attitudes. Effort is expected to be more important in the early stages of new behavior. And voluntariness of use shows if the usage is voluntary or mandated.

Modeling factors or mediators affect the four constructs of the model. Gender and age affect the performance expectancy, effort expectancy and social influence. Age and experience affect the facilitating conditions. Experience affects the effort expectancy, social influence and facilitating conditions. Voluntary use affects social influence in UTAUT.

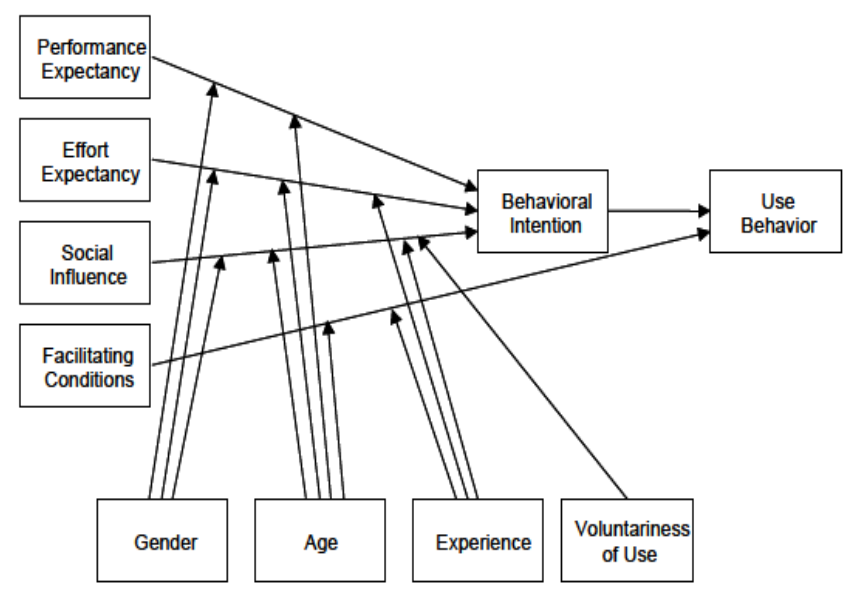

Fig. 2. Diagram of UTAUT theory (Venkatesh et al. 2003)

Figure 2, illustrates the UTAUT model that collects all variables from the eight existing models and their additional constructions (intermediaries). 


\section{REALIZED PROJECTS FOR IMPLEMENTATION OF E - LEARNING AT UGD}

In the last two decades, the constant imperative of teachers and professors was to introduce the use of ICT in the educational process. For this purpose, at all levels of education, various projects have been implemented to integrate ICT in teaching. In the Republic of Macedonia, this process has been especially emphasized in the last 10 years, through the implementation of several projects of national interest. These projects have been funded by USAID, European Council and Ministry of Education and Science of Republic of Macedonia.

Some of these projects, starting in 2005, were implemented through the Faculty of Pedagogy in Stip, and from 2007 through the University "Goce Delcev"Stip. The University "Goce Delcev" was founded in 2007 and integrates 13 faculties with more than 100 study programs in the three cycles of studies. The Faculty of Pedagogy joined the University on the date of its establishment. The University "Goce Delcev" - Stip is a leading institution in the implementation of new

technologies in the educational system of the Republic of Macedonia (Zdravev, 2010, 2011, 2012/2013).

Here, we would like to highlight two projects with a scope and duration which had a special significance for the Faculty of Pedagogy: Creative Teaching and Learning (USAID), Integrating E-Learning across the Teacher Curriculum (TEMPUS). Common feature of these projects was the fact that they were aimed at adapting the existing curriculum to better educate the prospective teachers. Other important project is the project "Implementation of LMS in teaching" which was organized as a part of the ICT implementation activities at the University, which was partly supported by the Fulbright Foundation.

Project "Creative Teaching and Learning" lasted from October 2002 to December 2009, and was implemented in three phases, with a total budget of about 3.5 million dollars provided by USAID. We were involved in the second phase. In the beginning of this phase the project included 11 teachers from the state pedagogical faculties in the Republic of Macedonia, 5 of which were from our Faculty. In this phase they had initial training in the use of ICT in the teaching process.

The second project, titled "Integrating E-Learning across the Teacher Curriculum" was within the TEMPUS program of the European Commission. It was launched in October 2006 and lasted until September 2009. Within this project study stays were realized in Groningen, Leuven and Edinburgh where twenty teachers from Macedonia were retrained for the application of ICT in the teaching process. As a result of this project in 2008 a system for e-learning, based on platform for management learning Moodle 1.9 was put into trial use.

University "Goce Delcev" was established in March 2007 and wherein its foundation a policy was adopted: "Goce Delcev" to be organized with the highest level of use of ICT in all areas of management, administration and teaching. Thus, by the end of 2008, computers for every employee of UGD were provided, more new classrooms and computer laboratories with interactive whiteboards were opened, a modern computer network was installed in the buildings and the campus was connected by secured optical connectivity.

Finally, the "implementation of LMS in teaching" as a part of the ICT activities of the University was introduced. As a result of these projects in September 2008 the Center for eLearning (CEU) was established. The main aim of this center is to introduce modern forms of learning at the University "Goce Delcev", new technologies (interactive whiteboards, graphic panels, multimedia software and hardware, audiovisual equipment, etc.), and permanent training of professors, teachers and students from universities and schools in the country. The development of the Internet and multimedia technologies are the foundation of e - learning.

\section{A. Center For Elearning At Ugd}

The Center for e-learning uses the Moodle platform, which tends to provide adequate support to the process of education at UGD, by developing the skills of students and teachers and by developing their competencies that are necessary for survival in the digital age. At the same time, this system offers a panel of tools that can be used for editing and enabling creation of courses for subjects and their planning. The term planning and editing of courses means setting learning materials (scripts, presentations, images ...), setting up one of the many communication tools (forums, chats, emails ...) and also setting tools for identification and assessment of student knowledge (quiz, seminar paper, homework ...) offered by the system. The system also offers 24-hour collaboration between users anytime and anywhere.

In July 2008 a version of Moodle 1.9 was put into use, but with regular and continuous upgrading today we are using the latest version of the system Moodle 2.7. In Table 1 we show the results of the usage of Moodle 2.7 platform for 2014, specifically the state of use for the month of February.

Table 1. Usage of Moodle 2.7 platform (24.02.2014)

\begin{tabular}{|l|l|}
\hline moodle & Total \\
\hline Number of courses & 2004 \\
\hline Number of users & 17184 \\
\hline Number of role assignments & 83312 \\
\hline Number of posts & 79793 \\
\hline Number of questions & 1548 \\
\hline Number of resources & 14919 \\
\hline Average number of participants & 41.78 \\
\hline Average number of course modules & 10.55 \\
\hline
\end{tabular}

The total number of users of the Moodle 2.7 platform is around 17,184, of whom 267 are professors, 145 associate professors, and the rest are students at the University "Goce Delcev" - Stip. Currently we have 2004 active courses, which means that the creators of courses have regular and constant control of their courses, of the content, activities and students affiliated to them.

Big influence on these data has the use of the elearning at UGD by students. From July 2008 until the 
end of 2009, the e-learning system worked as a trial platform, but in 2010 the use of the system became mandatory for all faculties within UGD. According to data presented in Table 2 it can be ascertained that we have continuous increasing usage of Moodle platform in the period December 2010 - December 2011 - November 2013 - February 2014.

Table 2. Usage of Moodle platform in the period from 2010 to 2014

\begin{tabular}{|l|l|l|l|l|}
\hline \multicolumn{2}{|c|}{ moodle } & \multicolumn{4}{|c|}{ Total } \\
\cline { 2 - 5 } & 12.2010 & 12.2011 & 21.11 .2013 & 24.02 .2014 \\
\hline $\begin{array}{l}\text { Number of } \\
\text { courses }\end{array}$ & 760 & 898 & 1816 & 2004 \\
\hline $\begin{array}{l}\text { Number of } \\
\text { users }\end{array}$ & 8202 & 10852 & 16598 & 17184 \\
\hline $\begin{array}{l}\text { Number of role } \\
\text { assignments }\end{array}$ & 43774 & 50581 & 75336 & 83312 \\
\hline $\begin{array}{l}\text { Number of } \\
\text { posts }\end{array}$ & 31804 & 24408 & 55814 & 79793 \\
\hline $\begin{array}{l}\text { Number of } \\
\text { questions }\end{array}$ & 2294 & 1600 & 1291 & 1548 \\
\hline $\begin{array}{l}\text { Number of } \\
\text { resources }\end{array}$ & 8258 & 10828 & 13734 & 14919 \\
\hline
\end{tabular}

From this table it can be seen that in the period from December 2010 to February 2014 the number of courses has increased by approximately $163.68 \%$ or from 760 to 2004 courses and the number of users has increased by $109.51 \%$, from 8202 to 17,184 users.

\section{UTAUT SURVEY}

According to the UTAUT model (Figure 3) basic four key determinants are important for determining user acceptance of the new Information Systems (Venkatesh et al, 2003). These determinants are Performance Expectancy, Effort Expectancy, Social influence and Facilitating conditions.

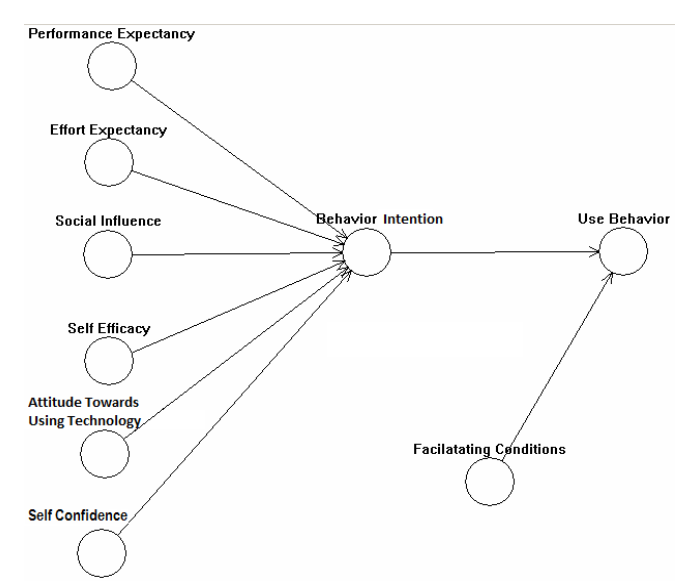

Fig. 3. Research model of the paper

But our research model also contains determinants involved in other research models such as Self-Efficacy and Attitude toward Using Technology, and one personal determinant "Self - Confidence". These additional determinants will also serve us for better coming to the conclusion regarding the acceptance and use of the elearning system and it is assumed that their inclusion would strengthen the study and would improve the support for UTAUT. The four basic determinants are influenced by the four key factors including gender, age, experience and voluntary use. Figure 3 graphically shows the relationship between the variables used in this study.

Participants in this study were the teaching staff of the University "Goce Delcev" (professors, assistants, laboratory assistants and lecturers). 138 responded the survey, but 92 gave a complete answer to the survey, so analysis is done only on those 92 samples. The total number of teaching staff within the University is around 360.

A. Results From The Survey Conducted For The Use And Acceptance Of The E-Learning System By Applying The Utaut Theory

In order to come to some conclusions about the acceptance and use of the e - learning system, a survey was conducted on the teaching staff of the University "Goce Delcev" - Stip. The survey consisted of 31 questions referring to the e - learning system and 9 questions / statements were about the demographic structure of the population.

From Table 3 we can see that the majority of respondents are female, that most of them are between the age of 30 and 44 and most of them have full-time work with more than 10 years of working experience. Also, according to the analysis we conclude that most of the respondents are professors who teach more than 5 subjects and use the e - learning system once or several times a day.

Table 3. Demographic Characteristics of Respondents

\begin{tabular}{|l|l|l|l|}
\hline $\begin{array}{l}\text { Demographic } \\
\text { characteristics }\end{array}$ & Responses & Occurrence & Percent \\
\hline Gender & Male & 37 & 40,22 \\
& Female & 55 & 59,78 \\
\hline \multirow{3}{*}{ Age } & to 30 & 13 & 14,13 \\
& from 30 to 44 & 45 & 48,91 \\
& above 45 & 34 & 36,96 \\
\hline \multirow{2}{*}{ Working status } & Part-time & 5 & 5,43 \\
& Full-time & 87 & 94,57 \\
\hline \multirow{2}{*}{ Working } & 1-5 years & 18 & 19,57 \\
experience & 6-10 years & 28 & 30,43 \\
\hline \multirow{5}{*}{ Education level } & More than 10 years & 46 & 50 \\
& Professor & 54 & 58,70 \\
& Assistant & 33 & 35,87 \\
& Lecturer & 1 & 1,09 \\
Scope of work & Laboratory assistant & 4 & 4,35 \\
\hline & course & 1 & 1,09 \\
& 2-3 courses & 13 & 14,13 \\
& 4-5 courses & 35 & 38,04 \\
& More than 5 courses & 43 & 46,74 \\
\hline \multirow{5}{*}{ I use } & once or several times & 39 & 42,39 \\
system & a day & 37 & 40,22 \\
& once a week & 12 & 13,04 \\
& once a month & 3 & 3,26 \\
& once a year & 1 & 1,09 \\
\hline \multirow{2}{*}{ never } & & \\
\hline
\end{tabular}

B. Descriptive analysis

The descriptive statistical analysis is elaborated in this section in order to provide a broader understanding of academics acceptance and use of the e-learning system in teaching and learning within the University "Goce 
Delcev" - Stip. The questions of the survey, referring to the e - learning are divided into 8 categories of issues and they are all given in Table 4 in the following order:

Table 4. Questions for e-learning system N=92 ( $\mathrm{N}=$ number of respondents))

\begin{tabular}{|c|c|c|c|c|c|}
\hline $\begin{array}{l}\text { Questi } \\
\text { ons }\end{array}$ & 5 & 4 & 3 & 2 & 1 \\
\hline PE1 & $\begin{array}{l}53,26 \% \\
(49)\end{array}$ & $\begin{array}{ll}41,30 & \% \\
(38) & \end{array}$ & $\begin{array}{ll}4,35 \% \\
(4)\end{array}$ & $\begin{array}{l}0 \\
(0)\end{array}$ & $\begin{array}{ll}1,09 & \% \\
(1) & \end{array}$ \\
\hline PE2 & $\begin{array}{l}43.48 \% \\
(40)\end{array}$ & $\begin{array}{ll}44.56 \% \\
(41)\end{array}$ & $\begin{array}{l}6.52 \% \\
(6)\end{array}$ & $\begin{array}{ll}4.35 & \% \\
(4) & \end{array}$ & $\begin{array}{l}1.09 \% \\
(1)\end{array}$ \\
\hline PE3 & $\begin{array}{l}27.17 \% \\
(25)\end{array}$ & $\begin{array}{ll}41.30 \% \\
(38)\end{array}$ & $\begin{array}{l}20.65 \% \\
(19)\end{array}$ & $\begin{array}{l}9.78 \% \\
(9)\end{array}$ & $\begin{array}{l}1.09 \% \\
\text { (1) }\end{array}$ \\
\hline PE4 & $\begin{array}{ll}9.78 \% \\
(9)\end{array}$ & $\begin{array}{ll}41.30 \% \\
(38)\end{array}$ & $\begin{array}{ll}25 & \% \\
(23) & \\
\end{array}$ & $\begin{array}{l}18.48 \% \\
(17)\end{array}$ & $\begin{array}{l}5.43 \% \\
(5)\end{array}$ \\
\hline EE1 & $\begin{array}{l}42.39 \% \\
(39)\end{array}$ & $\begin{array}{ll}40.22 \% \\
(37)\end{array}$ & $\begin{array}{l}10.87 \% \\
(10)\end{array}$ & $\begin{array}{ll}4.35 & \% \\
(4) & \\
\end{array}$ & $\begin{array}{ll}2.17 & \% \\
(2) & \\
\end{array}$ \\
\hline EE2 & $\begin{array}{ll}50 & \% \\
(46) & \end{array}$ & $\begin{array}{l}36.96 \% \\
(34)\end{array}$ & $\begin{array}{l}8.70 \% \\
(8)\end{array}$ & $\begin{array}{l}3.26 \% \\
(3)\end{array}$ & $\begin{array}{l}1.09 \% \\
\text { (1) }\end{array}$ \\
\hline EE3 & $\begin{array}{l}46.74 \% \\
(43)\end{array}$ & $\begin{array}{ll}42.39 \% \\
(39)\end{array}$ & $\begin{array}{l}4.35 \% \\
(4)\end{array}$ & $\begin{array}{l}4.35 \% \\
(4)\end{array}$ & $\begin{array}{ll}2.17 & \% \\
(2) & \end{array}$ \\
\hline EE4 & $\begin{array}{l}58.70 \% \\
(54)\end{array}$ & $\begin{array}{ll}28.26 \% \\
(26) & \\
\end{array}$ & $\begin{array}{ll}7.61 \% \\
(7)\end{array}$ & $\begin{array}{l}5.43 \% \\
(5)\end{array}$ & $\begin{array}{l}0 \\
0 \\
(0)\end{array}$ \\
\hline SI1 & $\begin{array}{l}31.52 \% \\
(29)\end{array}$ & $\begin{array}{ll}30.43 & \% \\
(28) & \\
\end{array}$ & $\begin{array}{ll}23.91 \% \\
(22)\end{array}$ & $\begin{array}{ll}8.70 & \% \\
(8) & \\
\end{array}$ & $\begin{array}{l}5.43 \% \\
(5)\end{array}$ \\
\hline SI2 & $\begin{array}{l}34.78 \% \\
(32)\end{array}$ & $\begin{array}{ll}29.35 & \% \\
(27) & \\
\end{array}$ & $\begin{array}{l}21.74 \% \\
(20)\end{array}$ & $\begin{array}{ll}7.61 \% \\
(7)\end{array}$ & $\begin{array}{l}6.52 \% \\
(6)\end{array}$ \\
\hline $\mathrm{SI} 3$ & $\begin{array}{l}53.26 \% \\
(49)\end{array}$ & $\begin{array}{ll}27.17 & \% \\
(25) & \\
\end{array}$ & $\begin{array}{l}11.96 \% \\
(11)\end{array}$ & $\begin{array}{ll}7.61 \% \\
(7)\end{array}$ & $\begin{array}{ll}0 & \% \\
(0) & \end{array}$ \\
\hline SI4 & $\begin{array}{l}76.09 \% \\
(70)\end{array}$ & $\begin{array}{ll}19.57 & \% \\
(18) & \\
\end{array}$ & $\begin{array}{ll}4.35 & \% \\
(4) & \\
\end{array}$ & $\begin{array}{l}0 \\
(0) \\
\end{array}$ & $\begin{array}{l}0 \\
(0) \\
\end{array}$ \\
\hline $\mathrm{FC} 1$ & $\begin{array}{l}65.22 \% \\
(60)\end{array}$ & $\begin{array}{ll}28.26 & \% \\
(26) & \end{array}$ & $\begin{array}{l}3.26 \% \\
(3)\end{array}$ & $\begin{array}{l}2.17 \% \\
(2)\end{array}$ & $\begin{array}{ll}1.09 \% \\
\text { (1) }\end{array}$ \\
\hline $\mathrm{FC} 2$ & $\begin{array}{l}63.04 \% \\
(58)\end{array}$ & $\begin{array}{ll}30.43 & \% \\
(28) & \end{array}$ & $\begin{array}{ll}4.35 \% \\
(4)\end{array}$ & $\begin{array}{l}1.09 \% \\
(1)\end{array}$ & $\begin{array}{l}1.09 \\
(1)\end{array}$ \\
\hline FC3 & $\begin{array}{l}13.04 \% \\
(12)\end{array}$ & $\begin{array}{ll}28.26 \% \\
(26) & \\
\end{array}$ & $\begin{array}{l}34.78 \% \\
(32)\end{array}$ & $\begin{array}{l}19.57 \% \\
(18)\end{array}$ & $\begin{array}{ll}4.35 \% \\
(4)\end{array}$ \\
\hline $\mathrm{FC} 4$ & $\begin{array}{ll}66.3 & \% \\
(61) & \end{array}$ & $\begin{array}{l}23.91 \% \\
(22)\end{array}$ & $\begin{array}{ll}8.7 & \% \\
(8) & \end{array}$ & $\begin{array}{l}1.09 \\
(1)\end{array}$ & $\begin{array}{l}0 \\
0)\end{array}$ \\
\hline BI1 & $\begin{array}{l}71.74 \% \\
(66)\end{array}$ & $\begin{array}{ll}19.57 & \% \\
(18) & \end{array}$ & $\begin{array}{l}5.43 \% \\
(5)\end{array}$ & $\begin{array}{l}2.17 \\
(2)\end{array}$ & $\begin{array}{l}1.09 \\
(1)\end{array}$ \\
\hline BI2 & $\begin{array}{l}77.17 \% \\
(71)\end{array}$ & $\begin{array}{ll}14.13 \% \\
(13)\end{array}$ & $\begin{array}{ll}5.43 & \% \\
(5) & \\
\end{array}$ & $\begin{array}{l}3.26 \\
(3)\end{array}$ & $\begin{array}{l}0 \\
(0) \\
\end{array}$ \\
\hline BI3 & $\begin{array}{l}81.52 \% \\
(75)\end{array}$ & $\begin{array}{ll}11.96 \% \\
(11)\end{array}$ & $\begin{array}{ll}4.35 \% \\
(4)\end{array}$ & $\begin{array}{ll}1.09 & \% \\
(1) & \end{array}$ & $\begin{array}{l}1.09 \\
(1)\end{array}$ \\
\hline A1 & $\begin{array}{l}66.30 \% \\
(61)\end{array}$ & $\begin{array}{ll}19.57 & \% \\
(18) & \\
\end{array}$ & $\begin{array}{l}11.96 \% \\
(11)\end{array}$ & $\begin{array}{ll}1.09 \% \\
(1)\end{array}$ & $\begin{array}{l}1.09 \\
(1)\end{array}$ \\
\hline A2 & $\begin{array}{l}36.96 \% \\
(34)\end{array}$ & $\begin{array}{l}38.04 \% \\
(35)\end{array}$ & $\begin{array}{l}11.96 \% \\
(11)\end{array}$ & $\begin{array}{l}9.78 \% \\
(9)\end{array}$ & $\begin{array}{l}3.26 \\
(3)\end{array}$ \\
\hline A3 & $\begin{array}{l}34.78 \% \\
(32)\end{array}$ & $\begin{array}{ll}32.61 \% \\
(30)\end{array}$ & $\begin{array}{l}21.74 \% \\
(20)\end{array}$ & $\begin{array}{ll}7.61 \% \\
(7)\end{array}$ & $\begin{array}{l}3.26 \\
(3)\end{array}$ \\
\hline A4 & $\begin{array}{l}21.74 \% \\
(20)\end{array}$ & $\begin{array}{ll}28.26 & \% \\
(26) & \end{array}$ & $\begin{array}{l}34.78 \% \\
(32)\end{array}$ & $\begin{array}{l}8.7 \\
(8)\end{array}$ & $\begin{array}{l}6.52 \\
(6)\end{array}$ \\
\hline SE1 & $\begin{array}{l}38.04 \% \\
(35)\end{array}$ & $\begin{array}{ll}38.04 \% \\
(35)\end{array}$ & $\begin{array}{l}15.22 \% \\
(14)\end{array}$ & $\begin{array}{l}8.7 \\
(8)\end{array}$ & $\begin{array}{l}0 \\
(0)\end{array}$ \\
\hline SE2 & $41.3 \%$ & $\begin{array}{l}32.61 \% \\
(30)\end{array}$ & $\begin{array}{l}20.65 \% \\
(19)\end{array}$ & $\begin{array}{l}4.35 \\
(4)\end{array}$ & $\begin{array}{l}1.09 \\
\text { (1) }\end{array}$ \\
\hline SE3 & $\begin{array}{l}.13 \% \\
6)\end{array}$ & $\begin{array}{ll}43.48 \% \\
(40)\end{array}$ & $\begin{array}{l}10.87 \% \\
(10)\end{array}$ & $\begin{array}{l}4.35 \\
(4)\end{array}$ & $\begin{array}{l}2.17 \\
(2)\end{array}$ \\
\hline SE4 & $\begin{array}{l}38.04 \% \\
(35)\end{array}$ & $\begin{array}{ll}29.35 \% \\
(27) & \\
\end{array}$ & $\begin{array}{l}20.65 \% \\
(19)\end{array}$ & $\begin{array}{ll}7.61 & \% \\
(7) & \\
\end{array}$ & $\begin{array}{ll}4.35 \% \\
(4)\end{array}$ \\
\hline SC1 & $\begin{array}{l}16.30 \% \\
(15)\end{array}$ & $\begin{array}{ll}43.48 & \% \\
(40) & \end{array}$ & $\begin{array}{l}19.57 \% \\
(18)\end{array}$ & $\begin{array}{l}13.04 \% \\
(12)\end{array}$ & $\begin{array}{ll}7.61 & \% \\
(7) & \end{array}$ \\
\hline & $\begin{array}{l}14.13 \% \\
(13)\end{array}$ & $\begin{array}{ll}39.13 \% \\
(36) & \\
\end{array}$ & $\begin{array}{l}16.30 \% \\
(15)\end{array}$ & $\begin{array}{ll}17.39 \% \\
(16)\end{array}$ & $\begin{array}{l}13.04 \% \\
(12)\end{array}$ \\
\hline SC3 & $\begin{array}{l}26.09 \% \\
(24)\end{array}$ & $\begin{array}{ll}43.48 \% \\
(40)\end{array}$ & $\begin{array}{l}14.13 \% \\
(13)\end{array}$ & $\begin{array}{l}10.87 \% \\
(10)\end{array}$ & $\begin{array}{l}5.43 \% \\
(5)\end{array}$ \\
\hline $\mathrm{SC} 4$ & $\begin{array}{l}39.13 \% \\
(36)\end{array}$ & $\begin{array}{l}42.39 \% \\
(39)\end{array}$ & $\begin{array}{l}9.78 \% \\
(9)\end{array}$ & $\begin{array}{l}5.43 \quad \% \\
(5)\end{array}$ & $\begin{array}{l}3.26 \% \\
(3)\end{array}$ \\
\hline
\end{tabular}

*Full questions are given in the Appendix
1. Questions related to the performance of using the system.

2. Questions related to the effort which should be invested for using the system.

3. Questions related to the social influence.

4. Questions related to the facilitating conditions for using the system.

5. Questions related to the behavioral intention of the system.

6. Questions related to the attitude of the individual to use the technology.

7. Questions related to the self - efficacy of using the system.

8. Questions related to the self - confidence of using the system.

Respondents were asked to rate their level of agreement with each statement or question with appropriate responses on a five item Likert scale.

According to the Likert scale: (1) means "strongly disagree", (2) means "disagree", (3) means "neither agree nor disagree (neutral)", (4) means "agree", and (5) means "strongly agree".

From the tables 4 and 5, we can see that performance expectancy has a mean response of 15.87 and standard deviation of 3.56. Answers to questions about the performance expectancy (PE1 - PE4) are associated with the extent to which an individual believes that using the e-learning system will improve its efficiency. The results from the survey show that $75.54 \%$ agreed that the e learning system makes tasks easier feasible, thereby it can increase productivity and the opportunity for professional and academic advancement.

The factor effort expectancy has a mean response of 17.15 and standard deviation of 3.54. Answers to questions about the effort expectancy (EE5 - EE8) are related to the degree of ease / simplicity associated with the use of a particular system. Total results for this category of issues are assessed as positive with individual ability to easily use and understand the current system, which is easy and simple to use. The results show that $86.41 \%$ agreed that they could use the system, and only $5.71 \%$ did not agree that the use of system is easy and simple.

Social influence is the degree to which an individual sees that others believe he or she should use the e learning system. This factor has a mean response of 16.5 and standard deviation of 3.82. A sufficient part of respondents i.e. $75.54 \%$ agree with the views of this category of issues, while $15.76 \%$ were neutral or neither agree nor disagree with these views. In general, the senior management of UGD supports and contributes to successful use of the system in teaching process and learning. Question 11 (SI3) has a positive response with $80.43 \%$ of respondents who "agree" or "strongly agree."

Facilitating conditions are defined as the degree to which an individual believes that an organizational and technical infrastructure exist to support the use of the e learning system. The factor facilitating conditions has a 
mean response of 16.88 and standard deviation of 3.23 . Questions 13, 14 and 16 were assessed as very positive with $79.62 \%$ of respondents who have the necessary resources to use the system, the respondents also say that they have the knowledge to use the system and that their institution has a department for support that is available to users who need help. In this case the sector for support is the E-learning Center.

Behavioral intention has a mean response of 13.96 and standard deviation of 2.21 and defines the goals or plans for use of the e-learning system by teaching staff of the University "Goce Delcev" - Stip. Thus, if one person has the intention to use the system that means that, that person probably will do it, so the intention is a good predictor of use. The total results for this category of questions are quite positive i.e. on issues 17,18 and 19 with agree and strongly agree responded $91.30 \%, 91.30 \%$ and $93.48 \%$ respectively. In this factor the percentage of those who do not plan to use the system, or are not sure whether to use it or not, is very small.

Table 5. Descriptive statistics

\begin{tabular}{|l|l|l|l|l|l|}
\hline & N & Min. & Max. & Mean & SD \\
\hline PE & & & & $\mathbf{1 5 . 8 7}$ & $\mathbf{3 . 5 6}$ \\
PE1 & 92 & 1 & 5 & 4.46 & 0.7 \\
PE2 & 92 & 1 & 5 & 4.25 & 0.84 \\
PE3 & 92 & 1 & 5 & 3.84 & 0.97 \\
PE4 & 92 & 1 & 5 & 3.32 & 1.05 \\
\hline EE & & & & $\mathbf{1 7 . 1 5}$ & $\mathbf{3 . 5 4}$ \\
EE1 & 92 & 1 & 5 & 4.16 & 0.94 \\
EE2 & 92 & 1 & 5 & 4.32 & 0.85 \\
EE3 & 92 & 1 & 5 & 4.27 & 0.9 \\
EE4 & 92 & 2 & 5 & 4.40 & 0.85 \\
\hline SI & & & & $\mathbf{1 6 . 5}$ & $\mathbf{3 . 8 2}$ \\
SI1 & 92 & 1 & 5 & 3.74 & 1.15 \\
SI2 & 92 & 1 & 5 & 3.78 & 1.19 \\
SI3 & 92 & 2 & 5 & 4.26 & 0.94 \\
SI4 & 92 & 3 & 5 & 4.72 & 0.54 \\
\hline FC & & & & $\mathbf{1 6 . 8 8}$ & $\mathbf{3 . 2 3}$ \\
FC1 & 92 & 1 & 5 & 4.54 & 0.75 \\
FC2 & 92 & 1 & 5 & 4.53 & 0.73 \\
FC3 & 92 & 1 & 5 & 3.26 & 1.05 \\
FC4 & 92 & 2 & 5 & 4.55 & 0.70 \\
\hline BI & & & & $\mathbf{1 3 . 9 6}$ & $\mathbf{2 . 2 1}$ \\
BI1 & 92 & 1 & 5 & 4.59 & 0.78 \\
BI2 & 92 & 2 & 5 & 4.65 & 0.73 \\
BI3 & 92 & 1 & 5 & 4.72 & 0.70 \\
\hline A & & & & $\mathbf{1 5 . 8 3}$ & $\mathbf{4 . 0 9}$ \\
A1 & 92 & 1 & 5 & 4.49 & 0.82 \\
A2 & 92 & 1 & 5 & 3.96 & 1.08 \\
A3 & 92 & 1 & 5 & 3.88 & 1.07 \\
A4 & 92 & 1 & 5 & 3.5 & 1.12 \\
\hline SE & & & & $\mathbf{1 6 . 1 6}$ & $\mathbf{3 . 9 3}$ \\
SE1 & 92 & 2 & 5 & 4.05 & 0.94 \\
SE2 & 92 & 1 & 5 & 4.09 & 0.94 \\
SE3 & 92 & 1 & 5 & 4.13 & 0.92 \\
SE4 & 92 & 1 & 5 & 3.89 & 1.13 \\
\hline SC & & & & $\mathbf{1 3 . 1 7}$ & $\mathbf{4 . 7 3}$ \\
SC1 & 92 & 1 & 5 & 2.99 & 1.24 \\
SC2 & 92 & 1 & 5 & 2.98 & 1.29 \\
SC3 & 92 & 1 & 5 & 3.44 & 1.16 \\
SC4 & 92 & 1 & 5 & 3.76 & 1.04 \\
\hline Valid N & 92 & & & $\mathbf{1 2 5 . 5 2}$ & $\mathbf{2 9 . 1 1}$ \\
\hline
\end{tabular}

Factor attitude toward using technology has a mean response of 15.83 and standard deviation of 2.21. Answers to questions about the attitude toward using technology (A20 - A23) are associated with the degree to which an individual believes that he or she should use the system. The total results for this category of issues are assessed as partly positive with $69.57 \%$ who said that they agree with these views that the use of the system is a good idea and it is interesting, and approximately $30.43 \%$ do not agree with these views.

Self - efficacy is the degree to which an individual judges his or her ability to use an e-learning system to accomplish a particular job or task. $75 \%$ of respondents believe that they can finish the job or task using the system for e-learning if there is someone who can help them and if they have time. Self - efficacy has a mean response of 16.16 and a standard deviation of 3.93 .

We define the new factor "self-confidence" as the degree of self-confidence without anxiety associated with the use of the e - learning system. Here we can see that $66.03 \%$ agree with the views that are convinced that they can use the system and are not afraid in losing important information, $19.2 \%$ are anxious and feel fear, and the rest $14.95 \%$ are neutral. Although here we have more positive responses, it is good because it indicates that the teaching staff is ready to use the system and is not upset and is not afraid to use it.

The descriptive statistics is briefly presented in Table 5 . It provides information on each issue separately and information for the lowest and highest grade given to this issue, the total number of respondents for each question respectively, and information regarding the middle grade on response and deviations from the mean grade (standard deviation).

To calculate the relationship between two determinants we use the correlation coefficient $r$, which is also called the coefficient of linear correlation. This coefficient ranges from -1 to 1 . If $r$ is closer to 1 , then the variables have a positive correlation; else if they are closer to -1 have a negative correlation. Generally, correlation greater than 0.8 are described as strong, and the correlation less than 0.5 are described as weak. In our case the correlation coefficients between BI and other factors are shown in Figure 4. We can see that all determinants have good or strong correlation, only SC has weak correlation with BI.

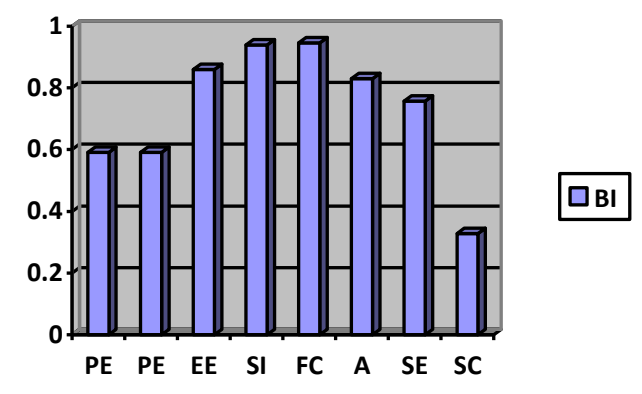

Fig. 4. Correlation between the BI and other factors

\section{CONCLUSION}

This paper mainly focuses on the intent of the academic staff to accept and use the e - learning system 
within the University "Goce Delcev" - Stip. Considering that academics are crucial for effective use of the elearning in higher education, it is important to understand their behavior intentions to the system and the factors that influence these intentions. Adopting and modifying the UTAUT model, we added a new construct of self confidence and applied it to the local context for predicting the role of self-confidence in higher education adoption and use. We found that self - confidence doesn't play a crucial role in the adoption and use of e-learning system. The conducted survey shows that the use of the e - learning is mandatory, but the level of adoption among university academic staff is a medium, and the factor 'lack of sufficient time' is indicated as the main and biggest reason for not using the system. Among the seven UTAUT factors, the effort expectancy (86.4\%) and facilitating conditions have the strongest effect (79.62\%). Therefore they are the most influential factors for acceptance and use of the system by the respondents That means that respondents' interaction with the system for elearning is clear and understandable and that they have the necessary resource to use the system. Also according to the survey, social influence and facilitating conditions are in strongest correlation with the behavioral intention (Figure 4) and thereby the most influence on the behavior of participants for acceptance and use of the e - learning system.

\section{APPENDIX. SURVEY ITEMS}

Questions for e-learning system

Performance Expectancy (PE)

1. I find the system for e-learning useful in my job. (PE1)

2. Using the system for e-learning enables me to accomplish tasks more easily. (PE2)

3. Using the system for e-learning increases my productivity. (PE3)

4. If I use the system for e-learning, it will increase my chance for progress. (PE4)

\section{Effort Expectancy (EE)}

5. My interaction with the system for e-learning is clear and understandable. (EE1)

6. It is simple for me to use the system for e-learning. (EE2)

7. It will be simple to operate with the system for elearning. (EE3)

8. The knowledge of using the system for e-learning is simple for me. (EE4)

\section{Social influence (SI)}

9. People who influenced my action believe that I should use the system for e-learning. (SI1)

10. People who are important to me think I should use the system for e-learning. (SI2)
11. The senior management of our institution (UGD) has been helpful in the use of the system for elearning. (SI3)

12. In general, UGD has supported the use of the system for e-learning. (SI4)

\section{Facilitating conditions (FC)}

13. I have the resources necessary to use the system for e-learning. (FC1)

14. I have adequate ability to operate with the system for e-learning. (FC2)

15. The system for e-learning did not match the other systems I operate. (FC3)

16. Some people are present to help me with problems regarding the system for e-learning. (FC4)

\section{Behavioral intention (BI)}

17. I guess I can operate the system for e-learning in six months. (BI1)

18. I predict I will use the system for e-learning in the next six months. (BI2)

19. I plan to use the system for e-learning in the next six months. (BI3)

\section{Attitude toward Using Technology (A)}

20. Using the system for e-learning is a good idea. (A1)

21. The system for e-learning makes work more interesting. (A2)

22. Working with the system for e-learning is fun. (A3)

23. I like working with the system for e-learning. (A4)

\section{Self-Efficacy (SE)}

24. I could finish the work of system for e-learning ... if there is somebody available to assist. (SE1)

25. I could complete the job or task using the system for e-learning ... if I could call someone for help if I got stuck. (SE2)

26. I can finish the work with system for e-learning if I have enough time. (SE3)

27. I could complete the job or task using the system for e-learning ... if I had just built-in help facility for assistance. (SE4)

\section{Self-confidence (SC)}

28. The use of the system for e-learning doesn't upset me. (SC1)

29. I am not afraid that I could lose information using the system for e-learning. (SC2)

30. My self-confidence does not allow me to fear to use the system for e-learning. (SC3)

31. I am convinced that I can use the system for elearning without any problem. (SC4)

Demographic information: 
32. Gender: $1=$ male, $2=$ female.

33. Age: $1=$ to $30,2=$ from 30 to $44,3=$ above 45 .

34. Working status: $1=$ Part-time, $2=$ Full-time

35. Working experience: $1=1-5$ years, $2=6-10$ years, $3=$ more than 10 years.

36. Education level 1= Professor, 2=Assistant, 3= Lecturer, 4=Laboratory Assistant.

37. Scope of work $1=0-1$ course, $2=2-3$ courses, $3=4-5$ courses, $4=$ more than 5 courses.

38. Is the use of system for e-learning mandatory or voluntary in your institution? $1=$ mandatory $2=$ voluntary.

39. I use the e-learning system: $1=$ once or several times a day, $2=$ once a week, $3=$ once a month, $4=$ once a year, $5=$ never.

40. Which are the largest barriers for using the elearning system according to you? 1=time, $2=$ technical support, $3=$ cost, $4=$ training, $5=$ does not fit my program, $6=$ other.

\section{REFERENCES}

[1] Allah Nawaz,Muhammad Zubair Khan (2012). Issues of Technical Support for e-Learning Systems in Higher Education Institutions, IJMECS, vol.4, no.2, pp.38-44.

[2] Amani J. Algharibi, Theodoros N. Arvanitis. (2011). Adapting the Unified Theory of Acceptance and Use of Technology (UTAUT) as a Tool for Validating User Needs on the Implementation of e-Trial Software Systems. BCS-HCI ' 11 Proceedings of the 25th BCS Conference on Human-Computer Interaction, 526-530.

[3] Bens Pardamean, Mario Susanto, Harisno. (2011). Acceptance of Blog Technology in e-Business Course. EActivities, 185-190.

[4] Carmen C. Lewis, Cherie E. Fretwell, Jim Ryan, James B. Parham. (2013). Faculty Use of Established and Emerging Technologies in Higher Education: A Unified Theory of Acceptance and Use of Technology Perspective. International Journal of Higher Education, 22-34.

[5] Chang, C.-C. (2013). Library mobile applications in university libraries. Emerald, 478-492.

[6] Christer Carlsson, Joanna Carlsson, Kaarina Hyvönen, Jussi Puhakainen, Pirkko Walden. (2006). Adoption of Mobile Devices/Services - Searching for Answers with the UTAUT. Proceedings of the 39th Hawaii International Conference on System Sciences, 1-10.

[7] E. AbuShanab, J.M. Pearson. (2012). Emerald Article: Internet banking in Jordan: The unified theory of acceptance and use of technology (UTAUT) perspective. Journal of Systems and Information Technology Emerald, 78 - 97.

[8] Héctor San Martín, Ángel Herrero. (2012). Influence of the user's psychological factors on the online purchase intention in rural tourism: Integrating innovativeness to the UTAUT framework. Tourism Management, 341-350.

[9] II Im, Seongtae hong, Myung Soo Kang. (2011). An international comparison of technology adoption Testing the UTAUT model. Information \& Management, 48, 1-8.

[10] J.Moran, M. (2006). College student's acceptance of tablet personal computers: a modification of the UTAUT. Capella University.
[11] Michail N. Giannakos,Panayiotis Vlamos. (2011). Identifying the Predictors of Educational Webcasts' Adoption. Innovation and Technology in Computer Science Education, 376.

[12] Mike Wade, Scott Schneberger. (2005, September 30). Retrieved from The Theories Used in IS Research: http://www.istheory.yorku.ca/UTAUT.htm.

[13] Mohammed Alshehri, Steve Drew, Rayed AlGhamdi. (2012). Analusis of citizens' acceptance for e-government services: Applying the UTAUT model. IADIS International Conferences Theory and Practice in Modern Computing and Internet Applications and Research.

[14] N.D. Oye, N. A. Iahad, Zairah Ab. Rabin. (2011). A Model of ICT Acceptance and Use for Teachers in Higher Education Institutions. International Journal of Computer Science \& Communication Networks, 22-40.

[15] Mirjana Kocaleva, Igor Stojanovik, Zoran Zdravev. (2014). UTAUT and its application in an educational environment: State-of-the Art. Yearbook 2013 - Faculty of Computer Science, 2 (2). pp. 95-102. ISSN 1857- 8691.

[16] Mirjana Kocaleva, Igor Stojanovik, Zoran Zdravev. (2014). Research on UTAUT Application in Higher Education Institutions. ITRO 2014, 27 June 2014, Zrenjanin, Serbia. pp. 34-39.

[17] Viswanath Venkatesh, James Y. L. Thong, Xin Xu. (2012). Consumer acceptance and use of information technology: extending the unified theory of acceptance and use of technology. MIS Quarterly, 157-178.

[18] Viswanath Venkatesh, Michael G. Morris, Gordon B. Davis, Fred D. Davis. (2003). User acceptance of information technology: Toward a unified view. MIS Quarterly, 425-478.

[19] Zahraa F. Muhsen,Adi Maaita,Ashraf Odah,Ayman Nsour (2013). Moodle and e-learning Tools, IJMECS, vol.5, no.6, pp.1-8.

[20] Zoran Zdravev. (2010). Integrating ICT in Teachers Education - Case study at "Goce Delcev" University. BASOPED - 13th International Conference - ICT in the education of the Balkan countries.

[21] Zoran Zdravev, Gorgi Dimov, Silvana Krsteva . (2011). E-learning in Higher Education through E-learning center. Conference for Informatics and Information Technology, 1-4.

[22] Zoran Zdravev, Silvana Zezova, Gorgi Dimov. (2012/2013). E-learning implementation aT ugd - lessons learned. Vospitanie br.12, 149-158.

\section{Authors' Profiles}

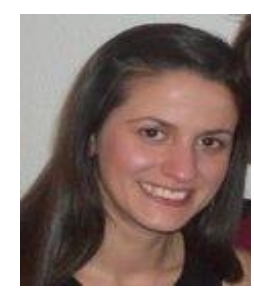

Mirjana Kocaleva received a Master degree in Information Systems, Department of Information Technology at Faculty of Computer Science at University "Goce Delcev" - Stip, Macedonia in 2014. Her present position is a volunteer in the E-learning Center - ELC and at the Faculty of Computer Science at the University "Goce Delcev". She is a participant in several projects and her research interests include Information Systems and Technologies in higher education, E-Learning Systems and Applied Mathematics. 


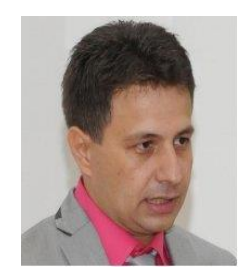

Igor Stojanovic earned a M.Sc. degree in 2002 and a Ph.D degree in 2011, both from Ss. Cyril and Methodius University in Skopje. He also received a Ph.D degree in 2014 from University of Nis, Serbia. Currently he is an assistant professor at the Faculty of Computer Science at University "Goce Delcev" - Stip, Macedonia. His research interests are Information Systems, Business Process Modeling, Digital Video and Image Processing.

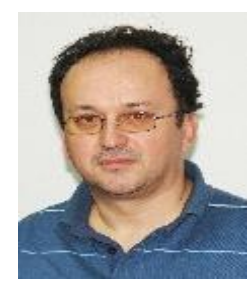

Zoran Zdravev received the $\mathrm{PhD}$ degree in Computer Science from the Faculty of Natural Sciences and Mathematics Skopje, Ss. Cyril and Methodius University in Skopje in 2011. Since 2009 he serve as head of E-Learning Center at "Goce Delcev" University Stip, he is assistant professor at Faculty of Computer Science at University "Goce Delcev" - Stip, and head of Information Technologies Department. His research interest is in Information Systems, E-Learning Systems, Digital Repositories and Natural Language Processing.

How to cite this paper: Mirjana Kocaleva, Igor Stojanovic, Zoran Zdravev,"Model of e-Learning Acceptance and Use for Teaching Staff in Higher Education Institutions", IJMECS, vol.7, no.4, pp.23-31, 2015.DOI: 10.5815/ijmecs.2015.04.03 